\title{
Risk factors of postpartum uterine infection and its subsequent effect on fertility of crossbred dairy cows in Bangladesh
}

\author{
Hossain $\mathrm{MK}^{1 *}$, Uddin $\mathrm{AHMM}^{1}$, Yasmin $\mathrm{N}^{1}$, Hossain $\mathrm{MM}^{2}$, Lucky NS ${ }^{1}$, Haque MM ${ }^{1}$, \\ Aktaruzzaman $\mathrm{M}^{4}$ and Alam $\mathrm{S}^{3}$ \\ ${ }^{1}$ Department of Surgery and Theriogenology, ${ }^{2}$ Department of Medicine, ${ }^{4}$ Department of Pharmacology and \\ Toxicology, Faculty of Veterinary and Animal Science, Sylhet Agricultural University, Sylhet-3100, Bangladesh; \\ ${ }^{3}$ Department of Livestock services, Pabna, Bangladesh
}

[Received: July 23, 2015; Accepted: August 04, 2015]

\begin{abstract}
Postpartum uterine infection is extremely important in dairy cattle. It is both common and detrimental to reproductive performance. The present study was conducted to investigate the factors responsible for postpartum uterine infection and its subsequent effect on fertility of crossbred dairy cows in Chatmohar Upazila, Pabna District. A total of 317 cows were selected and registered and then follow up them in postpartum period. Reproductive histories and data of the studied cows were assessed by direct interviewing and from record book of the owners and nearby government veterinary hospital. Totally 33 cows were found uterine infected $(10.41 \%)$ in postpartum period. The case of pyometra was substantially higher in present study in contrast to others. The incidence of uterine infection puerperal metritis, pyometra and endometritis were $1.89 \%, 5.99 \%$ and $2.52 \%$ respectively. Dairy cattle calving season and parity reflected greatly on the incidence of uterine infection. Potentially significant $(\mathrm{p}<0.05)$ and higher incidence of uterine infection were associated with poor management system where minimum complications were found with good management practice $(3.20 \%)$ compared to poor management farms. The dairy cows suffering from endometritis significantly showed prolonged days to first estrus interval, days open and number of services per conception and calving interval values $(68.5 \pm 0.05$ days; $115.4 \pm 0.4$ days , $4.75 \pm 0.50$, and $398 \pm 6$ respectively) than normal healthy cows. Further researches in the near future must be directed for prevention of uterine infection, as most of effective treatments don't prevent the negative impacts of such disease upon dairy, reproduction and culling percentage within dairy herd.
\end{abstract}

Key words: Risk factors, uterine infection, fertility, cross breed cows

\section{INTRODUCTION}

Postpartum uterine infection is extremely important in dairy cattle. It is both common and detrimental to reproductive performance. The major diseases of the postpartum period are puerperal metritis, pyometra and endometritis. There is a relationship between uterine infection and fertility of dairy cows. In general, cows with severe uterine contamination are slow to ovulate in the postpartum period. This combination allows a purulent exudate to develop and accumulate in the uterine lumen. In general, cows with pyometra are effectively treated with a luteolytic agent. Accordingly, Shamsuddin et al., (1988) studied the occurrence reproductive diseases in large government dairy farm and identified Puerperal metritis (10.4\%), Pyometra (8.2\%) and Endometritis (27.4\%) as major reproductive diseases in Bangladesh.

The decreased fertility is caused by negative effects in the uterus and in the ovary. Uterine diseases cause lesions in the endometrium ${ }^{[2]}$, disrupt endometrial function [3], and impair embryo development ${ }^{[4,5]}$. These complications are responsible for slower uterine involution, reduced reproductive rate, prolonged inter conception and calving interval, cost of medication, drop in milk production, reduced calf drop, and early depreciation of potentially useful cows ${ }^{[6,7,8]}$. Uterine diseases decrease luteinizing hormone, first dominant follicle size and growth, and follicular ability to secrete estradiol, therefore affecting ovulatory capacity $[9,10$, 11]. After postpartum ovulation resumes, cows that developed uterine disease present prolonged luteal phases [12, 13], which can decrease time to insemination and conception rates. Cows with uterine infection in the early postpartum period generally have lower conception rates at subsequent breedings. This effect would likely have been more severe if the herds had not been participating in a routine herd health program in which uterine infections and other postpartum reproductive problems were detected and treated early. However, very limited studies have been conducted to determine the risk factors of postpartum uterine infection and its consequence on fertility of crossbred dairy cows in Bangladesh.

Accordingly, the objective of this study was to determine risk factors of postpartum uterine infection and its consequence on fertility of crossbred dairy cows in Bangladesh

\section{MATERIALS AND METHODS}

\section{Site profile and geographical information}

The present study was conducted for a period of twelve month from January 2015 to December 2015 in Chatmohar Upazila, pabna District. Pabna District area $2371.50 \mathrm{sq} \mathrm{km}$, located in between $23^{\circ} 48^{\prime}$ and $24^{\circ} 21^{\prime}$ north latitudes and in between $89^{\circ} 00^{\prime}$ and 
$89^{\circ} 44^{\prime}$ east longitudes. It is bounded by Natore and Sirajgang districts on the north, Padma river, Rajbari and Khustia districts on the south, Manikganj and Sirajganj districts and Jamuna river on the east, Padma River, Natore and Kushtia districts on the west. Chatmohar Upazila (Pabna District) area $305.63 \mathrm{sq} \mathrm{km}$, located in between $24^{\circ} 06^{\prime}$ and $24^{\circ} 21^{\prime}$ north latitudes and in between $89^{\circ} 12^{\prime}$ and $89^{\circ} 24^{\prime}$ east longitudes. It is bounded by Gurudaspur and Taras upazilas on the north, Atgharia upazila on the south, Faridpur (Pabna) and Bhangura upazilas on the east, Baraigram and Gurudaspur upazilas on the west ${ }^{[14]}$. postpartum period. A regular visit of the farms was carried out to collect data on the major postpartum reproductive problems of dairy cows. Finally, parturient cows were grouped in to those giving birth without any problem and those giving birth with problems according to the following definitions.

Puerperal Metritis: It is characterized by systemic disease within 10-15 days usually with fever, a foetid, watery, reddish-colored uterine discharge, and uterine flaccidity ${ }^{[15,16]}$.

Endometritis: An inflammation of the uterine wall characterized by reddish brown, white or whitish to yellow mucopurulent, with fetid

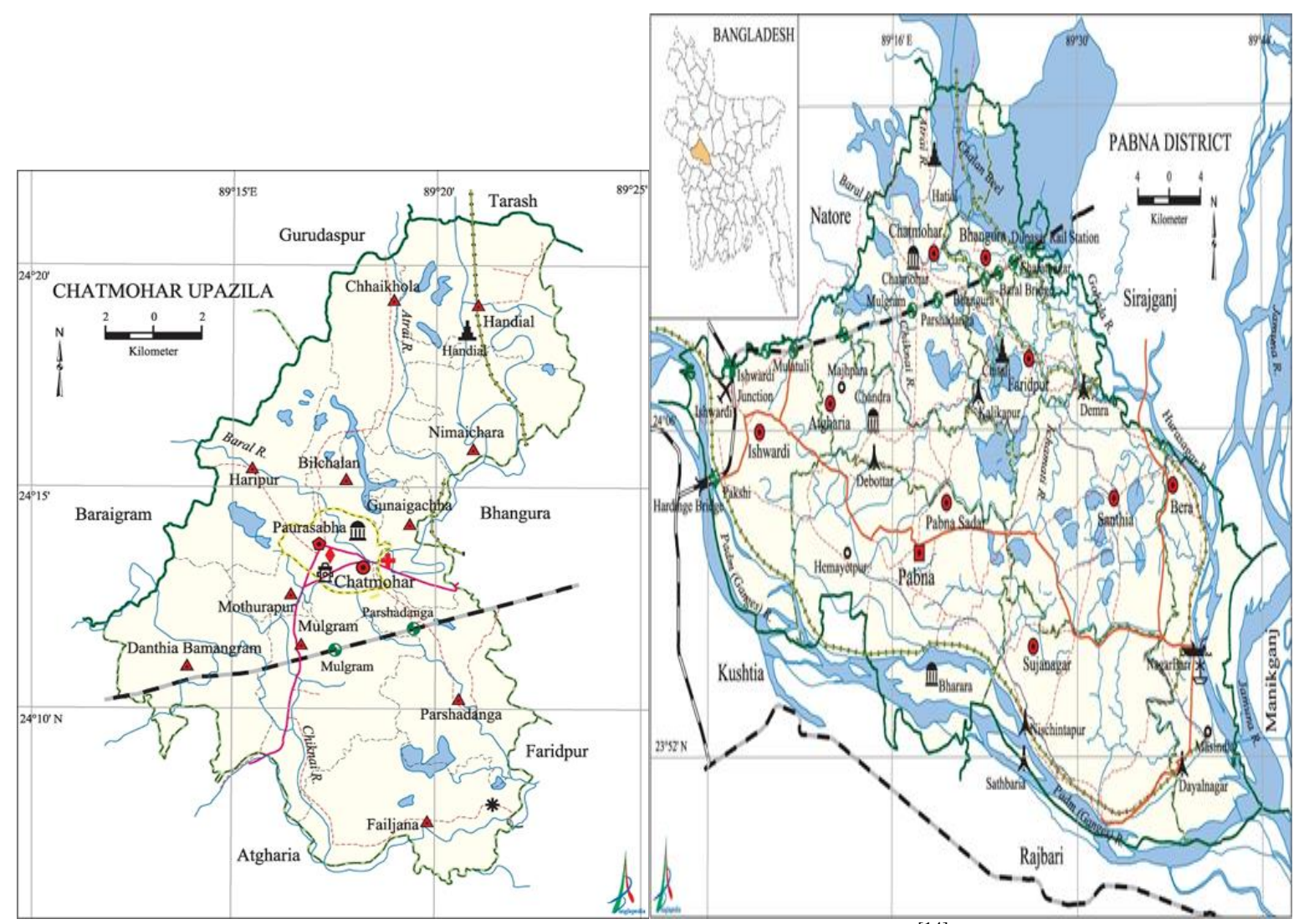

Fig.1. Geographical location of the study area Chatmohar, Pabna, Bangladesh ${ }^{[14]}$

\section{Study population}

The population of the present study was crossbred dairy cows in respective dairy farm. A observational survey method was applied in dairy farms up to their parturition period. Reproductive histories of the studied cows were assessed by direct interviewing and from record book of the owners and near by government veterinary hospital. At the beginning of the study, 317 cows were selected and registered and then follow up them in pre and postpartum period.

\section{Study methodology}

All study animals were selected and identified by individual tag number/ID. Then all necessary information: breed, age, parity, date of service, date of calving, Estrous after last calving, conception rate, service per conception, milk production rate, managemental system, body condition score, reproductive complications before and after vaginal discharge along with thickness of uterine wall at transrectal palpation $[15,16,17]$.

Pyometra: The condition in which progressive accumulation of pus in the uterus and there is persistence of functional corpus luteum ${ }^{[18]}$.

Dystocia: A condition in which difficulty in birth during parturition and the cow required assistance $[16,18,19]$.

RFM: A lack of Seperation of the placenta with in the first $24 \mathrm{~h}$ after calving $[16,17,18,19]$.

\section{Procedure of Body condition score system}

Body condition was scored in order to assess the bony prominence and deposition of subcutaneous fat and animals were grouped in to $0,1,2,3,4$ and 5 body condition scores according to Richard (1993) [20]

\section{Data management and statistical analysis}


Regular collected informative data was entered to a Microsoft Excel sheet 2007 and analyzed using a software SPSS ® version 12. The different risk factors (that is, parity, body condition score,
(Table 1). The expulsion of placenta had significant effect on post partum uterine infection.

The case of pyometra was substantially higher in present study in contrast to others. The incidence of

Table 1: Incidence of uterine infection with associated risk factors in cross breed dairy cows

\begin{tabular}{|c|c|c|c|c|c|c|c|}
\hline \multirow[b]{2}{*}{ Variables } & \multirow[b]{2}{*}{$\begin{array}{l}\text { No. of cows } \\
\text { examined }\end{array}$} & \multicolumn{3}{|c|}{ Uterine infection } & \multirow{2}{*}{$\begin{array}{c}\text { Sub total } \\
\begin{array}{c}(\% \text { of } \\
\text { incidence })\end{array}\end{array}$} & \multirow[b]{2}{*}{$\begin{array}{c}\text { chi } \\
\text { square }\end{array}$} & \multirow[b]{2}{*}{$\mathrm{P}$ value } \\
\hline & & $\begin{array}{l}\text { Puerperal } \\
\text { Metritis }\end{array}$ & Pyometra & Endometritis & & & \\
\hline Placental expulsion & 317 & & & & & & \\
\hline Normal expelled & 284 & & & & & & \\
\hline RFM & 33 & $6(1.89 \%)$ & $\begin{array}{l}19(5.99 \\
\%)\end{array}$ & $8(2.52 \%)$ & $\begin{array}{l}33(10.41 \\
\%)\end{array}$ & & \\
\hline \multicolumn{8}{|l|}{ Effect of Season } \\
\hline Summer & 174 & $11(6.32$ & $15(8.62$ & $4(2.29 \%)$ & $30(17.24$ & & \\
\hline Rainy & 98 & $\%)$ & $\%)$ & $0(0.00 \%)$ & $\%)$ & 6.89 & 0.032 \\
\hline Winter & 55 & $\begin{array}{l}2(2.04 \%) \\
3(5.45 \%)\end{array}$ & $\begin{array}{l}2(2.04 \%) \\
2(3.63 \%)\end{array}$ & $1(1.81 \%)$ & $\begin{array}{l}4(4.08 \%) \\
6(10.90 \% \\
)\end{array}$ & & \\
\hline \multicolumn{8}{|l|}{ Parity } \\
\hline 1 & 82 & $2(2.43 \%)$ & $6(7.31 \%)$ & $1(1.21 \%)$ & $9(10.97 \%$ & & \\
\hline 2 & 71 & $1(1.40 \%)$ & $4(5.63 \%)$ & $2(2.81 \%)$ & ) & & \\
\hline 3 & 61 & $1(1.63 \%)$ & $3(4.91 \%)$ & $0(0.00 \%)$ & $7(9.85 \%)$ & 9.04 & 0.107 \\
\hline 4 & 45 & $1(2.22 \%)$ & $1(2.22 \%)$ & $0(0.00 \%)$ & $4(6.55 \%)$ & & \\
\hline 5 & 33 & $0(0.00 \%)$ & $1(3.03 \%)$ & $1(3.03 \%)$ & $2(4.44 \%)$ & & \\
\hline$>5$ & 25 & $2(8.00 \%)$ & $\begin{array}{l}5(20.00 \\
\%)\end{array}$ & $0(0.00 \%)$ & $\begin{array}{l}2(6.06 \%) \\
7(28.00 \% \\
)\end{array}$ & & \\
\hline \multicolumn{8}{|l|}{$\mathrm{BCS}$} \\
\hline$<3$ & 105 & $1(0.95 \%)$ & $2(1.90 \%)$ & $1(0.95 \%)$ & $4(3.80 \%)$ & & \\
\hline $3.0-4.0$ & 117 & $6(5.12 \%)$ & $15(12.82$ & $2(1.70 \%)$ & $23(19.65$ & 10.23 & 0.005 \\
\hline$>4.0$ & 95 & $2(4.21 \%)$ & $\begin{array}{l}\%) \\
4(4.21 \%)\end{array}$ & $0(0.00 \%)$ & $\begin{array}{l}\%) \\
12(12.63 \\
\%)\end{array}$ & & \\
\hline \multicolumn{8}{|l|}{ Management } \\
\hline Medium & 99 & $3(3.03 \%)$ & $7(7.075)$ & $2(2.02 \%)$ & $12(12.12$ & 10.97 & 0.004 \\
\hline Poor & 93 & $5(5.37 \%)$ & $\begin{array}{l}10(10.75 \\
\%)\end{array}$ & $2(2.15 \%)$ & $\begin{array}{l}\%) \\
17(18.27 \\
\%)\end{array}$ & & \\
\hline
\end{tabular}

season, dystocia, Retained fetal membrane) that were considered during the study period were analyzed using the Chi square technique. The analysis was considered $\mathrm{p}<.05$ for establishing significance.

\section{RESULTS AND DISCUSSION}

Among the studied 317 crossbred dairy cows of Chatmohor upazilla (Sub district), 33 cows were found uterine infected $(10.41 \%)$ in postpartum period uterine infection puerperal metritis, pyometra and endometritis were $1.89 \%, 5.99 \%$ and $2.52 \%$ respectively (Table 1). Dairy cattle calving season reflected greatly on the incidence of uterine infection. In the summer calving season the highest incidence uterine infection was found $(13.79 \%)$ compared with different calving seasons and it was might be due to warm temperature in environment during that season. This result was in agreement with Gaafar et al. [21], where they reported that the incidence of the uterine infection increased during summer and spring calving seasons. 
Table 2: Consequence of Uterine Infection on Reproductive Performance in Cross Breed Dairy Cows

\begin{tabular}{lcccc}
\hline $\begin{array}{l}\text { Uterine status } \\
\text { of the cows }\end{array}$ & $\begin{array}{c}\text { Calving to first } \\
\text { estrus interval } \\
\text { (days) }\end{array}$ & $\begin{array}{c}\text { Days open } \\
\text { (days) }\end{array}$ & $\begin{array}{c}\text { Service per } \\
\text { conception (N) }\end{array}$ & $\begin{array}{c}\text { Calving } \\
\text { intervals(days) }\end{array}$ \\
\cline { 2 - 5 } & Mean \pm SE & Mean \pm SE & Mean \pm SE & Mean \pm SE \\
\hline Metritis & $56.3 \pm .03$ & $110.5 \pm 0.5$ & $2.50 \pm 0.50$ & $385 \pm 5$ \\
Endrometritis & $68.5 \pm 0.5$ & $115.4 \pm 0.4$ & $4.75 \pm 0.50$ & $398 \pm 6$ \\
Pyometra & $49.4 \pm 0.4$ & $105.6 \pm 0.6$ & $3.65 \pm 0.75$ & $390 \pm 4$ \\
Healthy & $43.2 \pm 0.2$ & $86.2 \pm 0.2$ & $1.85 \pm 0.10$ & $316 \pm 6$ \\
\hline
\end{tabular}

It was clearly that the incidence ratio of uterine infection was increased in old dairy cows which had parity numbers over 5 and it was about $28.00 \%$ (Table 1). Similar type of result was found by those of Deyab, Gabr et al., Gaafar et al. ${ }^{[21-23]}$.The cows which had body condition score within 3.0-4.0 also showed higher incidence of uterine infection(19.65\%) significantly compared to other scale. The results were similar to the findings of Dawod et al. ${ }^{[24]}$ and Gaafar et al. ${ }^{[21]}$.The incidence of the uterine infection increased with increasing of the fat tissue deposition and cow's body weight [21]. In fatty cows the steroid sex hormones trapped via excessive fat deposition, as these hormones are known to be fat soluble hormones. Potentially significant $(\mathrm{p}<0.05)$ and higher incidence of uterine infection were associated with poor management system where minimum complications were found with good management practice $(3.20 \%)$ compared to poor management farms (Table 1). Management system reported to be plays consistently critical role in occurring uterine infection. The result was in agreement with the findings of Uddin et al. ${ }^{[25]}$

From Table 2, it was evident that the reproductive performance possessed significant difference among different uterine status in cross bred dairy cows of studied areas. The dairy cows suffering from endometritis significantly showed higher level of days to first estrus interval, days open and number of services per conception and calving interval values (68.5 \pm 0.05 days; $115.4 \pm 0.4$ days , $4.75 \pm 0.50$, and $398 \pm 6$ respectively) than normal healthy cows (43.20 \pm 0.2 days; $86.2 \pm 0.2$ days, 1.85 and $316 \pm 6$ respectively). Good reproductive efficiency is an important factor for production economy in a dairy herd. Uterine infections are the most common cattle diseases that can be a significant cause of poor reproduction [26-27]. Uterine diseases have been associated with increased service per conception, extended days open, increased culling and economic losses [28-30]

\section{CONCLUSION}

Uterine infection had great negative impacts upon high yielding Holstein cows productive and reproductive performance even after efficient treatment, as it could be decreased the milk yield. Also, it increased days to first estrus, days open and number of services per conception. Moreover, concern must be given to the dairy females, which calving during summer seasons, as these seasons have high prevalence of puerperal metritis. Dairy producers must be focusing their efforts to detect puerperal metritis within the first ten days of the postpartum period. Since most of such cases appeared during this period by a rate of $89.98 \%$. Attention should be taken to reappearance of the puerperal metritis during successive lactation seasons in the dairy females whom had a history of puerperal metritis as this disease had tended to be recurrent. Further researches in the near future must be directed to prevention of uterine infection, as most of effective treatments don't prevent the negative impacts of such disease upon dairy, reproduction and culling percentage within dairy herd.

\section{REFERENCES}

1. Shamsuddin M, Alam MGS and Ahmed JU (1988). Reproductive disorders of crossbred cows. Bangladesh Veterinary Journal, 22: 2128 .

2. Bonnett BN, Martin SW, Gannon VPJ, Miller RB and Etherington WG (1991). Endometrial biopsy in Holstein-Friesian dairy cows. III. Bacterial analysis and correlations with histological findings. Canadian Journal of Veterinary Research,55:168-173.

3. Sheldon IM and Dobson H (2004). Postpartum uterine health in cattle. Animal Reproduction Science, 82/83:295-306.

4. Soto P, Natzke RP and Hansen PJ (2003). Actions of tumor necrosis factor-alpha on oocyte maturation and embryonic development in cattle. American Journal of Reproduction Immunology, 50:380-388

5. Hill J and Gilbert R (2008). Reduced quality of bovine embryos cultured in media conditioned by exposure to an inflamed endometrium. Australian Veterinary Journal, 86:312-316.

1. 6. Thomas C (1989). A preliminary survey on infertility aspects of selected dairy farms around Addis Ababa. A seminar presented to the orientation course in Tropical Animal and Health Production, Addis Ababa University, Faculty of Veterinary Medicine, DebreZeit, Ethiopia

6. Barnouin J and Chacronac JP (1992). A nutritional risk factor for early metritis in 
dairy farms in France. Preventive Veterinary Medicine, 13: 23-27.

7. Merga B (1992). Farm animal Obstetrics. Addis Ababa University, Faculty of Veterinary Medicine, DebreZeit, Ethiopia

8. Peter AT, Bosu WT and DeDecker RJ (1989). Suppression of preovulatory luteinizing hormone surges in heifers after intrauterine infusions of Escherichia coli endotoxin. American Journal of Veterinary Research, 50:368-373

9. Sheldon IM, Noakes DE, Rycroft AN, Pfeiffer DU and Dobson H (2002). Influence of uterine bacterial contamination after parturition on ovarian dominant follicle selection and follicle growth and function in cattle. Reproduction, 123:837-845.

10. Williams EJ, Sibley K, Miller AN, Lane EA, Fishwick J, Nash DM, Herath S, England GC, Dobson H and Sheldon IM (2008). The effect of escherichia coli lipopolysaccharide and tumour necrosis factor alpha on ovarian function. American Journal of Reproductive Immunology, 60:462-473.

11. Opsomer G, Gröhn YT, Hertl J, Coryn M, Deluyker H and de Kruif A (2000). Risk factors for post partum ovarian dysfunction in high producing dairy cows in Belgium: a field study. Theriogenology, 53:841-857.

12. Mateus L, da Costa LL, Bernardo F and Silva JR (2002). Influence of puerperal uterine infection on uterine involution and postpartum ovarian activity in dairy cows. Reproduction in Domestic Animals 37:31-35.

13. Banglapedia (2015). National Encyclopedia of Bangladesh. Asiatic Society of Bangladesh, Dhaka,Bangladesh.http://en.banglapedia.org/i mages/f/fb/PabnaDistrict.jpghttp://en.banglape dia.org.

14. Morrow DA (1980).Current therapy in theriogenology. Diagnosis, treatment and prevention of reproductive diseases in animals. W.B. Saunders Company, Philadelphia.

15. Roberts SJ (1986). Veterinary obstetrics and genital diseases. Theriogenology, $3^{\text {rd }}$ edition. Edwards's brothers, Inc., Michigan, 48-104.

16. Bekana M, Ekman T and Kindahl H (1994). Ultrasonography of the bovine postpartum uterus with retained fetal membrane. Journal of Veterinary Medicine, 41: 653-662

17. Arthur GH, Noakes DE and Pearson H (1989).Veterinary reproduction and Obstetrics. Theriogenology. $6^{\text {th }}$ edition. Bailler Tindal, United Kingdom, 83-85.
18. Noakes DE (1986). Fertility and Obstetrics in cattle.Oxford (UK) Blackwell Science Publication. pp. 28-30.

19. Richard W (1993). Dairying. Tropical Agriculturalist. 1st Ed. Macmillan Press Ltd. London. 43-48.

20. Gaafar HMA, Shamiah ShM, Shitta AA and Ganah HAB(2010). Factors Affecting Retention of Placenta and Its Influence on Postpartum Reproductive Performance And Milk Production In Friesian Cows. Slovak Journal of Animal Science. 43, 2010 (1): 6 12.

21. Gabr Sh A, Shamiah, ShM, Abu EL-Hamd M A (2005). Factors related to the incidence of retained placenta in Friesian cows kept under Egyptian conditions. Journal of Agriculture Science. Mansoura University, 2005, vol. 30, Pp. 6532.

22. Deyab HHS (2000). Factors affecting placenta retention in cattle. Ph. D. Fac. of Agric., 2000, Minufiya University.

23. Dawod A, Mostafa I, El-Baz H, Abdel-Hamid T and Fathala MM (2015).Risks of Some Postpartum Uterine Affection on Reproduction and Milk Yield of High Yielding Dairy Cows. Veterinary Science \& Technology. Vol 6, Issue 4 .Pp 1-5

24. Uddin AHMM, Hossain MK, Lucky NS, Roy AC, Islam MR, Uddin ASMA and Hossain MM (2015). Prevalence and risk factors of pre and postpartum complications in crossbred dairy cows of Sylhet, Bangladesh. Annals of Veterinary and Animal Science . Vol.4, issue2. $\mathrm{Pp}-109-115$

25. Gilbert RO, Gröhn YT, Miller PM and Hoffman DJ(1993).Effect of Parity on Periparturient Neutrophil Function in Dairy Cows. Veterinary Immunology and Immunopathology. 36:75-82.

26. Overton M and Fetrow J (2008). Economics of postpartum uterine health. In: Proceedings of the Dairy Cattle Reproduction Council Convention, Omaha, NE, USA. Hartland, WI: DCRC 39-43.

27. Galvão KN, Frajblat M, Brittin SB, Butler WR and Guard CL. (2009) Effect of prostaglandin F2alpha on subclinical endometritis and fertility in dairy cows. Journal of Dairy Science 92: 4906-4913.

28. Fourichon C, Seegers H and Malher X (2000). Effect of disease on reproduction in the dairy cows; a meta-analysis. Theriogenelogy, 2000, vol. 53, p. 1729-1759. 